\title{
El-Fayah
}

JURNAL BIOLOGI

Journal Homepage: http://ejournal.uin-malang.ac.id/index.php/bio/index

e-ISSN: 2460-7207, p-ISSN: 2086-0064

Original research article

\section{The Effect of Compost From Household Waste and Liquid Organic Fertilizer On Growth and Yield of Pak Choi (Brassica rapa Var. Chinensis)}

\section{Amik Krismawati ${ }^{1}$ and Sugiono}

${ }^{1}$ East Java Assessment Institute for Agricultural Technology (AIAT East Java) Indonesia Agency for Agriculture Research and Development Ministry of Agriculture

*Corresponding author

Email: krismawati_amik@yahoo.com

DOI: 10.18860/elha.v8i2.12315

\section{Article Info}

Article history:

Received 09 November 2020

Received in revised form

11 January 2021

Accepted 03 March 2021

Key Word:

Compost made of household

waste

Liquid organic fertilizer

Growth

Yield

Pak Choi

\begin{abstract}
A b s tract
Objectives of the research were to study and create a technique in producing compost made of organic wastes from the household and its effect on growth and increase productivity of Pak Choi. The research was conducted from January to February 2017 in Karangploso, Malang, East Java. The research applied RBD with 4 replications. The treatments comprised of 2 types, such as compost of household waste that consisted of 3 levels as follow $K_{1}=$ Organic wastes of household waste $100 \%+$ Superdegra decomposer + goat dropping + bran + molasses by dose $0.5 \mathrm{~kg} /$ polybag; $K_{2}=$ Organic waste from household waste $100 \%+$ Superdegra decomposer + goat dropping + bran + molasses by dose 1.0 $\mathrm{kg} /$ polybag; $\mathrm{K}_{3}=$ Organic waste from household waste $100 \%+$ Superdegra decomposer + goat dropping + bran + molasses by dose $1.5 \mathrm{~kg} /$ polybag. Treatment of different concentrations of liquid organic fertilizer consisted of three levels that include $C_{1}=20 \mathrm{ml} / 500 \mathrm{ml}$ water, $C_{2}=40$ $\mathrm{ml} / 500 \mathrm{ml}$ water, and $\mathrm{C}_{3}=60 \mathrm{ml} / 500 \mathrm{ml}$ water. Data analysis used Analysis of Variance (ANOVA) and followed by LSD at level 5\%. Results of analysis in the laboratory indicated that organic fertilizer from organic waste of the household waste $100 \%+$ Superdegra + goat dropping + bran + molasses produced $\mathrm{C}$-organic $=18.89$ and $\mathrm{C} / \mathrm{N}$-ratio $=17.33$. Combination of treatments, which include organic waste $\left(\mathrm{K}_{3} \mathrm{C}_{2}\right)$, will be able to produce Pak Choi 126.38 gram/polybag.

It is due to this crop contains excellent nutrients, which are good for human body, such as carbohydrate, protein, unsaturated fat, fiber, sodium, potassium, vitamin $A$ and $C$, and
\end{abstract}

\section{INTRODUCTION}

Pak Choi/Bok Choy (Brassica rapa var. Chinensis) is one of vegetable varieties, which is frequently consumed by Indonesian people. 
low fat (Price, 2010). Besides that, Pak Choi can be processed into diverse foods whether being stirred fry with coconut oil or being boiled. The Indonesian Statistic Board for Agriculture recorded the increasing demand for Pak Choi per capita per week, from 2011-2015, was about $14.98 \mathrm{~kg}$ and the demand per year was about $14,982 \mathrm{~kg}$ (Department of Agriculture, 2015).

The Indonesian Statistic Board for Agriculture recorded that percentage of Pak Choi availability from 2011 to 2014 increased $2.72 \%$ per year, while its availability per capita (kg/capita/year) decreased $0.53 \%$ (Department of Agriculture, 2015). Decrease production of Pak Choi was caused by some factors, and one of them was low nutrients availability in the soil as a result of continual land uses. Nutrients availability can only be increased and improved by applying fertilizer. Supplementing organic matter in the soil may affect on physical, biological, and chemical properties of the soil, however, and finally will affect on growth and development of the crop due to organic matter may function as nutrient sources and energy source for most of the organisms in the soil (Kusuma, 2002).

Fertilizer application may be given using various kinds of fertilizers, and one of them is organic fertilizer. Organic fertilizer can be processed from various organic substances, and one of them is derived from household wastes. Organic fertilizer from household waste is not only able to increase both macronutrients and micronutrients, but also able to increase soil structure. The organic fertilizer, such as compost, may increase NPK content and organic compounds in the soil, as well as loosen the soil, so that quality and quantity of the harvest will be increased (Edward, 2010). The application of organic fertilizers, for example, barnyard manure and green manure could improve properties of the soil. Kuruseng (2012) reported that the application of bokashi with the mixture of $40 \%$ cattle dropping plus 10\% straw, 40\% dried leaves of Gliricidia sepium, 10\% rice hull, and 1 kg dolomite lime have produced the best yield on growth and yield of Pak Choi.

Kind of liquid organic fertilizer, which is mostly used, except compost from organic waste of household waste, is foliar fertilizer that is applied on abaxial part of the leaf, which is rich of stomata as the access of nutrient to the leaf. Foliar fertilizer has some superiority, such as quick response toward the crop due to it can be absorbed directly by stomata, and may not damage the crop if it is applied properly, moreover, the effect of foliar fertilizer is relatively quicker, 1-2 weeks post the treatment, and the soil may not have physical damage quickly because of the fertilizer effect (Sarpian, 2003; Novizan, 2005). The previous research proved that the application of nitrogen-contained liquid fertilizer in Pak Choi was more efficient than being applied in the soil. Besides that, the application of fertilizer through foliages could overcome the tardiness in applying fertilizer into the soil (White et al., 2015).

Quality of the resulted crop through such fertilizer application can be increased effectively by applying combinations of two or more fertilizers. It is expected that the application combination of foliar fertilizer and soil applied fertilizer could promote growth and increase the crop yield. Besides that, the application of foliar fertilizer could overcome the usage load of soil applied fertilizer for about 50\% (Cruz et al., 2012). Objective of the research was to study the effect of compost application, which derived from household waste, and liquid organic fertilizer on growth and yield of Pak Choi (Brassica rapa var. Chinensis).

\section{MATERIALS AND METHODS}

The research was conducted in Kepuharjo Village, Karangploso Sub District, Malang District, from January to February 2017. The research was designed in Randomized Block Design (RBD), 3 replicates, and 9 treatments. The observed treatments were as treatment 
combination of the compost dose from liquid organic fertilizer (foliar fertilizer) (C) household waste $(K)$ and concentration of the with 4 replications. (Table 1 ).

Table 1. Treatment combination arrangement for fertilizer application in Pak Choi

\begin{tabular}{ll}
\hline Treatment & Description \\
\hline Compost from household $(\mathrm{K})$ & Dose $(\mathrm{kg})$ \\
\hline $\mathrm{K}_{1}$ & 0,5 \\
\hline $\mathrm{K}_{2}$ & 1,0 \\
\hline $\mathrm{K}_{3}$ & 1,5 \\
\hline \multirow{2}{*}{ Liquid organic fertilizer $(\mathrm{C})$} & Concentration of Liquid organic fertilizer per 500 \\
\hline $\mathrm{C}_{1}$ & $\mathrm{ml}$ air \\
\hline $\mathrm{C}_{2}$ & $20 \mathrm{ml}$ \\
\hline $\mathrm{C}_{3}$ & $40 \mathrm{ml}$ \\
\hline
\end{tabular}

\section{Implementation}

Planting medium used the mix of compost from household waste and soil in accordance with the appropriate ratio of the applied treatment. Compost from the household waste and soil were mixed evenly and then put it into polybag, $5 \mathrm{~kg}$ in volume. The planting medium was left for two days before planting.

Pak Choi (Brassica rapa var. Chinensis) is planted in planting medium in $5 \mathrm{~cm}$ depth. The crop was watered with $500 \mathrm{ml}$ water per polybag and labeled in accordance with the applied dose or concentration of the liquid organic fertilizer. The crop was put in a shaded place for 4 days and acclimatized. Then, the polybag was transferred to a place, where it got sufficient light and covered with paranet to reduce excessive light intensity, to prevent pest interference, and to prevent rainwater penetrate the planting medium excessively. Liquid organic fertilizer in accordance with each treatment was sprayed evenly on the abaxial part of the leaf. The spraying was applied at 06.30 to 08.00 WIB to maximize the fertilizer absorbed by the leaf.

\section{Observation}

The observed data include (1) chemical properties of the compost from organic waste of the household ( $\mathrm{pH}, \mathrm{C}$-organic, N-total, $\mathrm{C} / \mathrm{N}$ ratio, $\mathrm{P}_{2} \mathrm{O}_{5}, \mathrm{~K}_{2} \mathrm{O}, \mathrm{Na}, \mathrm{Ca}$, and $\mathrm{Mg}$, which were analyzed in the laboratory (Table 2), (2) Agronomic performance include plant height and numbers of leaf at 10, 14, 18, and 22 Days After Planting (DAP), as well as fresh weight of harvest yield (40 DAP).

Table 2. Result of chemical analysis on compost of the household waste at 4 weeks after incubation

\begin{tabular}{|c|c|c|c|c|c|c|c|c|c|}
\hline \multirow[b]{2}{*}{ Treatment } & \multicolumn{9}{|c|}{ Analysis } \\
\hline & $\mathrm{pH}$ & $\begin{array}{l}\text { C-organic } \\
(\%)\end{array}$ & $\begin{array}{l}\mathrm{N} \text {-total } \\
(\%)\end{array}$ & $\begin{array}{l}\mathrm{C} / \mathrm{N} \\
\text { Ratio }\end{array}$ & $\begin{array}{l}\mathrm{P}_{2} \mathrm{O}_{5} \\
(\%)\end{array}$ & $\begin{array}{l}\mathrm{K}_{2} \mathrm{O} \\
(\%)\end{array}$ & $\mathrm{Na}$ & $\mathrm{Ca}$ & $\mathrm{Mg}$ \\
\hline $\begin{array}{l}\text { Organic waste from } \\
\text { housefold waste } 10 \%+ \\
\text { Superdegra } \\
\text { decomposer }+ \text { goat } \\
\text { dropping + bran }+ \\
\text { molasses by dose } 1,5 \\
\text { kg/polybag }\left(\mathrm{K}_{3}\right)\end{array}$ & 8,0 & 18,89 & 1,29 & 17,33 & 1,09 & 1,22 & 0,46 & 5,33 & 0,63 \\
\hline
\end{tabular}

Source: Result of analysis of Soil Laboratory of AIAT East Java, 2017 


\section{Data Analysis}

The obtained data of observation was tested statistically using ANOVA (Analysis of Variance). Data from results of observation was tested using F-test in order to find out any difference of response to growth and fresh weight of Pak Choi for each of the tested treatment. Moreover, in order to find out any difference of average value among treatments, follow-up statistic test was performed using the Least Significant Difference (LSD) test at significance level 5\% (Gomez and Gomez, 1993; Sastrosupadi 2005). Equation of linear model for the Randomized Block Design is as follows :

$$
\begin{aligned}
& \text { In which : } Y_{\mathrm{ij}}=\mu+\tau_{\mathrm{i}}+\beta_{\mathrm{j}}+\varepsilon_{\mathrm{ij}} \\
& \mathrm{Y}_{\mathrm{ij}} \quad \begin{array}{l}
\text { observation value from treatment-i in } \\
\text { the group-j }
\end{array} \\
& \begin{array}{ll}
\mu & =\text { average value of population } \\
\tau_{\mathrm{i}} & =\text { additive effect of treatment-i } \\
\beta_{\mathrm{j}} & =\text { additive effect of the group-j } \\
\varepsilon_{\mathrm{ij}} & =\text { the effect of experimental galat from } \\
& \text { treatment-i in the group- } \mathrm{j}
\end{array}
\end{aligned}
$$

Based on linear model for the Randomized Block Design (RBD) above, the analysis of variance is obtained as follows :

Table 3. Analysis of Variance for Randomized Block Design

\begin{tabular}{lllll}
\hline Diverse Sources & Free Degrees & Sum of Squares & Middle Squared & F Count \\
\hline Group & $\mathrm{r}-1$ & $\mathrm{JKK}=\left(\sum \mathrm{JY} 2 \mathrm{~J} / \mathrm{t}\right)-(\mathrm{Y} 2 . . / \mathrm{rt})$ & $\mathrm{KTK}=\mathrm{JKK} /(\mathrm{r}-1)$ & $\mathrm{KTK} / \mathrm{K}^{\prime \prime}$ \\
\hline Treatment & $\mathrm{t}-1$ & $\mathrm{JKP}=\left(\sum \mathrm{JY} 2 \mathrm{~J} / \mathrm{r}\right)-(\mathrm{Y} 2 . . / \mathrm{rt})$ & $\mathrm{KTP}=\mathrm{JKP} /(\mathrm{t}-1)$ & $\mathrm{KTP} / \mathrm{K}^{\prime \prime}$ \\
\hline Error & $(\mathrm{r}-1)(\mathrm{t}-1)$ & $\mathrm{JKG}=\mathrm{JKT}-\mathrm{JKK}-\mathrm{JKP}$ & $\mathrm{KTG}=\mathrm{JKP} /(\mathrm{r}-1)(\mathrm{t}-1)$ & \\
\hline Total & $\mathrm{rt}-1$ & $\mathrm{JKP}=\left(\sum \mathrm{ij} \mathrm{I}_{2} \mathrm{ij}\right)-(\mathrm{Y} 2 . . / \mathrm{rt})$ & & \\
\hline
\end{tabular}

Sumber : Gasperz (1995)

\section{RESULTS}

\section{Plant Height, Numbers of Leaf, and Fresh Weight of Pak Choi}

Results on analysis of variance showed that the treatment of compost from household waste and liquid organic fertilizer have significant effect on plant height and number of leaf, and fresh of weight of Pak Choi $(p<0.05)$ at 22 Days After Planting (DAP), and fresh of weight of Pak Choi $(p<0.05)$ at 40 DAP (Table 4).

It showed that size and height of plant affect on speed of the plant growth. Plant height at 22 DAP showed the application of 1.0 $\mathrm{kg} /$ polybag compost from household waste and $40 \mathrm{ml} / 500 \mathrm{ml}$ water of liquid organic fertilizer (treatment $\mathrm{K}_{2} \mathrm{C}_{2}$ ) showed the highest plant height in maize, $15.81 \mathrm{~cm}$, but it did not show significant difference with the application of $1.0 \mathrm{~kg} /$ polybag compost from household waste and $60 \mathrm{ml} / 500 \mathrm{ml}$ water of

\begin{tabular}{|c|c|c|c|c|}
\hline \multirow[t]{2}{*}{ Code } & & $\begin{array}{l}\text { Plant Height } \\
(\mathrm{cm})\end{array}$ & $\begin{array}{l}\text { Numbers of } \\
\text { Leaf (Blade) }\end{array}$ & $\begin{array}{l}\text { Fresh Weight of } \\
\text { Pak Choi (Gram) }\end{array}$ \\
\hline & Treatments & 22 DAP & 22 DAP & 40 DAP \\
\hline $\mathrm{K}_{1} \mathrm{C}_{1}$ & $\begin{array}{l}\text { Compost from household } 0.5 \mathrm{~kg}+\text { liquid } \\
\text { organic fertilizer } 20 \mathrm{ml} / 500 \mathrm{ml} \text { air }\end{array}$ & $13,63^{a}$ & $8^{\mathrm{a}}$ & $71,88^{c}$ \\
\hline $\mathrm{K}_{1} \mathrm{C}_{2}$ & Compost from household $0.5 \mathrm{~kg}+$ liquid & $13,31^{\mathrm{a}}$ & $8^{\mathrm{a}}$ & $66,00^{\mathrm{a}}$ \\
\hline
\end{tabular}
liquid organic fertilizer (treatment $\mathrm{K}_{2} \mathrm{C}_{3}$ ), 15.13 $\mathrm{cm}$, and the application of $1.5 \mathrm{~kg} /$ polybag compost from household waste and $20 \mathrm{ml} / 500$ $\mathrm{ml}$ water of liquid organic fertilizer (treatment $\left.\mathrm{K}_{3} \mathrm{C}_{1}\right), 15.31 \mathrm{~cm}$.

Table 4. The effect of compost from household waste and liquid organic fertilizer on Plant Height, Numbers of Leaf, and Fresh Weight of Pak Choi. 


\begin{tabular}{|c|c|c|c|c|}
\hline & organic fertilizer $20 \mathrm{ml} / 500 \mathrm{ml}$ air & & & \\
\hline $\mathrm{K}_{1} \mathrm{C}_{3}$ & $\begin{array}{l}\text { Compost from household } 0.5 \mathrm{~kg}+\text { liquid } \\
\text { organic fertilizer } 20 \mathrm{ml} / 500 \mathrm{ml} \text { air }\end{array}$ & $14,38^{\mathrm{b}}$ & $9^{b}$ & $87,75^{\mathrm{cd}}$ \\
\hline $\mathrm{K}_{2} \mathrm{C}_{1}$ & $\begin{array}{l}\text { Compost from household } 1.0 \mathrm{~kg}+\text { liquid } \\
\text { organic fertilizer } 40 \mathrm{ml} / 500 \mathrm{ml} \text { air }\end{array}$ & $14,31^{b}$ & $8^{\mathrm{a}}$ & $74,00^{c}$ \\
\hline $\mathrm{K}_{2} \mathrm{C}_{2}$ & $\begin{array}{l}\text { Compost from household } 1.0 \mathrm{~kg}+\text { liquid } \\
\text { organic fertilizer } 40 \mathrm{ml} / 500 \mathrm{ml} \text { air }\end{array}$ & $15,81^{e}$ & $11^{\mathrm{e}}$ & $112,50^{\text {de }}$ \\
\hline $\mathrm{K}_{2} \mathrm{C}_{3}$ & $\begin{array}{l}\text { Compost from household } 1.0 \mathrm{~kg}+\text { liquid } \\
\text { organic fertilizer } 40 \mathrm{ml} / 500 \mathrm{ml} \text { air }\end{array}$ & $15,13^{\text {cde }}$ & $8^{a}$ & $75,50^{c}$ \\
\hline $\mathrm{K}_{3} \mathrm{C}_{1}$ & $\begin{array}{l}\text { Compost from household } 1.5 \mathrm{~kg}+\text { liquid } \\
\text { organic fertilizer } 60 \mathrm{ml} / 500 \mathrm{ml} \text { air }\end{array}$ & $15,31^{\text {cde }}$ & $10^{\mathrm{cd}}$ & $102,53^{\text {de }}$ \\
\hline $\mathrm{K}_{3} \mathrm{C}_{2}$ & $\begin{array}{l}\text { Compost from household } 1.5 \mathrm{~kg}+\text { liquid } \\
\text { organic fertilizer } 60 \mathrm{ml} / 500 \mathrm{ml} \text { air }\end{array}$ & $14,75^{\mathrm{bc}}$ & $10^{\mathrm{cd}}$ & $126,38^{\mathrm{e}}$ \\
\hline $\mathrm{K}_{3} \mathrm{C}_{3}$ & $\begin{array}{l}\text { Compost from household } 1.5 \mathrm{~kg}+\text { liquid } \\
\text { organic fertilizer } 60 \mathrm{ml} / 500 \mathrm{ml} \text { air }\end{array}$ & $15,00^{\mathrm{bcd}}$ & $9^{b}$ & $97,63^{d}$ \\
\hline
\end{tabular}

The application of $1.0 \mathrm{~kg} /$ polybag compost from household waste $+40 \mathrm{ml} / 500 \mathrm{ml}$ water of liquid organic fertilizer (treatment $\mathrm{K}_{2} \mathrm{C}_{2}$ ) increased $15.99 \%$ in comparison with the application of $0.5 \mathrm{~kg} /$ polybag compost from household waste and $20 \mathrm{ml} / 500 \mathrm{ml}$ water of liquid organic fertilizer (treatment $\mathrm{K}_{1} \mathrm{C}_{1}$ ). It indicated that supplementing organic fertilizer will be able to supplement organic contents in the soil, so that it could provide nutrients in the soil, which are needed by the plant. According to Djoehana (1986), the application of organic fertilizer is aimed to supplement organic materials in the soil and improve physical properties of the soil, particularly structure and porosity of the soil in order to supply sufficient nutrients for the crop.

\section{DISCUSSION}

Results of the research by Haryati et al. (2014) reported that high performance of Pak Choi showed significant difference between those two treatments, in which treatment $A=$ goat dropping (manure) + soil + hull/husk was higher than treatment $\mathrm{B}=$ organic waste + hull/husk at all ages of the plant, at 21, 42, and 63 DAP. It showed that Pak Choi responded to planting medium of goat dropping mixed with soil and hull/husk because they provide nutrients required by the plant.
Nitrogen contained in Urea and NPK "Phonska" is really beneficial for the plant growth and development, for example, make the leaves look greener and contain great amount of chlorophyll, which play important role in photosynthetic process, accelerate the plant height and supplement protein content of the plant (Dewanto et al., 2013).

Results of the research by Haryati et al. (2014) reported that high performance of Pak Choi by the treatment of organic waste + hull $/$ husk at 14 DAP $=5.5 \mathrm{~cm}, 21 \mathrm{DAP}=24.4 \mathrm{~cm}$, 28 DAP $=31.3 \mathrm{~cm}$, and 35 DAP $=15.9 \mathrm{~cm}$. According to Kusuma (2012), supplementing organic material into the soil may affect physical, biological, and chemical properties of the soil, and finally affect on growth and development of the plant due to organic materials are functioned as nutrients and energy source for most of organisms in the soil.

Compost may improve structure of planting medium in breeding crops. It is due to compost may increase granulation and soil aeration, so that $\mathrm{CO}_{2}$ release as a result of metabolism in roots and $\mathrm{O}_{2}$ absorption as reductor material of root cells would be optimal. Such good condition will trigger water absorption and increase nutrients. Compost may increase resistence and water absorption ability, as well as prevent excessive water 
content in planting medium. It is due to compost could provide optimal arrangement on size of the soil pores size, in which the planting medium would not too clayey or crumbly (Ganesan et al., 2015).

Compost may provide nutrients in longterm. It is due to compost has ability to release nutrients slowly (slow release) that based on compost decomposition with the planting medium. So that, compost has higher efficiency and less fertilizer which might be lost than liquid fertilizer, as well as inorganic fertilizer, such as NPK, in which both fertilizers are easily washed away by water flows and released to watery ecosystem (Wahyono et al., 2011).

Plant height of Pak Choi as parameter is affected by three factors. The first factor is position or angular angel of leaf, in which young leaf has angular angel almost $90^{\circ}$. Young leaves grow and their sizes develop along with the increase height of the plant. These leaves will gradually experience aging and will be substituted by younger leaves, so that the angular angel will decrease, as well as the plant height. The second factor is abiotic factor, such as light intensity and water supply. Such abiotic factors will affect the turgor pressure on Pak Choi, whereas it is a herbaceous, which is going to have senescence when it is exposed by excessive light intensity and high temperature, as well as lack of water in the medium. The third factor is the nutrients content in the soil. The research conducted by Boonsiri et al. (2009) showed that high content of $\mathrm{N}, \mathrm{P}$, and $\mathrm{K}$ in granular organic fertilizer brings about better plant height than bioextract water, which contains low N, P, as well as K, and significantly different.

Greater numbers of leaf in Pak Choi at 22 DAP were resulted by the treatment of $\mathrm{K}_{2} \mathrm{C}_{2}$ (1.0 kg compost from household waste +40 $\mathrm{ml} / 500 \mathrm{ml}$ water of liquid organic fertilizer), 11 leaves, but it did not show significant difference with the treatment of $K_{3} C_{1}(1.5 \mathrm{~kg}$ compost from household waste $+20 \mathrm{ml} / 500 \mathrm{ml}$ water of liquid organic fertilizer), 10 leaves, and $K_{3} C_{2}$ (1.5 kg compost from household waste $+40 \mathrm{ml} / 500 \mathrm{ml}$ water of liquid organic fertilizer), 10 leaves. It indicated that the increase dose of compost from household waste, in general, may affect the increase numbers of leaf.

Numbers of leaf relate to the photosynthetic process, the crop yield is determined by any activities in cells and tissues of the plant. Leaf is the important organ in plant where the photosynthetic process takes place. More leaves will increase light interception ability that make the photosynthetic activities to be optimal and produce higher assimilate. Therefore, the assimilate translocation to the plant organs will be greater and finally will affect on the resulted fresh weight (Nathania et al., 2012).

The guard cells on stomata increase the turgor pressure that lead to stomatal closing. Such stomatal closing reduces the nutrient absorption of the foliar fertilizer (Sarpian, 2003; Araujo et al., 2011). Spraying, which was performed during the wind blows hard, will accelerate the evaporation of foliar fertilizer, so that the fertilizer effectiveness will be reduced and failed. Besides that, the speed of foliar fertilizer absorption highly affect on effectiveness of the foliar fertilizer. The speed of foliar fertilizer absorption by the plant depends on types and brand of the fertilizer. In general, average speed of fertilizer absorption is 2-3 hours after application (Cahyono, 2005). So that, the appropriate time for spraying application is 2-3 hours before the wind blows hard, bright sunlight, or rainfall will maximize the nutrient absorption by stomata.

The significant effect of dose that related to the application of compost from household waste is based on nutrient completeness contained in each fertilizer. Compost from the household waste contains macronutrients that include C-organic 10.16-18.89\%, N-total 0.64$1.57 \%$, ratio $\mathrm{C} / \mathrm{N} 13.56-18.29 \%$, content of $\mathrm{P}_{2} \mathrm{O}_{5}$ $1.05-3.24 \%, \mathrm{~K}_{2} \mathrm{O} 0.41 \%-1.39 \%$. The content of Corganic and $\mathrm{N}$-total in compost will stimulate amino acids production as raw material or 
building block of protein and nucleic acid as building block in DNA or RNA. Such high production will increase cellular divison cycle on apical meristem, so that numbers of leaf will increase rapidly (Taiz and Eduardo, 2002).

Nitrogen contained in compost fertilizer is the raw material in establishing cytokinin and auxin hormones in plant. It is due to auxin has indole ring, in which such indole ring consists of nitrogen atom. According to Xu et al. (2015), the increasing concentration of nitrogen will stimulate the shoot growth and the increasing numbers of lateral shoots on paddy (Oryza sativa), which automatically will increase numbers of leaf. Nitrogen plays its role in delaying leaf development that relates to the stimulating production of cytokinin.

Nitrogen is the main requirement in expressing IPT gene, which express enzyme protein of isopentenyl transferase. The increasing production of isopentenyl transferase will be followed by the increasing biosynthesis of cytokinin. Cytokinin hormone will interact with cells to prevent the degraded chlorophyll and nutrient translocation as a result of excessive water stress (Kant, 2014). Therefore, in general, nitrogen will stimulate the development of shoots and prevent leaf senescence.

Results of the research by Haryati et al. (2014) reported that numbers of leaf at 14 DAP did not show any difference between the treatments, but at 21, 28, 35 DAP the treatment in planting medium A (goat dropping (barnyard manure) + hull/husk + soil) showed higher than treatment $B$ (organic waste + hull/husk). Soil medium mixed with hull/husk and goat dropping (manure) have some superiority, such as providing nutrients in the soil as planting medium, and burnt husk as one of organic materials could maintain soil moisture due to burnt husk, as one of organic material, has micro and macro pores that are almost balanced, so that it brings about good air circulation and high-water absorption ability. The application of barnyard manure as supplemental planting medium plays important role in improving soil structure, soil porosity, metal element fastener in the soil (chelate) and assists in binding water in the soil to maintain soil moisture (Silvia et al., 2012).

The decreasing efficiency of foliar fertilizer is also caused by nutrient mobility rate. Nutrient is categorized into two in accordance with ability of their mobility, for instance, mobile and immobile nutrients. Mobile nutrients are nutrients that can be translocated from old leaves to young leaves. Such nutrients include nitrogen, phosphate, potassium, magnesium, chlorine, zinc, and molybdenum. Immobile nutrients are nutrients that cannot be translocated from the old leaves to the young ones. Such nutrients include calcium, sulphur, iron, boron, and copper (Taiz and Eduardo, 2002).

Results on analysis of variance showed that dose of compost from household waste and concentration of the liquid organic fertilizer have significant effect on fresh weight of Pak Choi. The highest fresh weight of Pak Choi has been obtained by treatment $\mathrm{K}_{3} \mathrm{C}_{2}$ (1.5 kg compost from household waste + $40 \mathrm{ml} / 500 \mathrm{ml}$ water of liquid organic fertilizer) 126.38 gram, but did not show significant difference by the treatments of $\mathrm{K}_{2} \mathrm{C}_{2}, \mathrm{~K}_{3} \mathrm{C}_{1}$, and $\mathrm{K}_{3} \mathrm{C}_{3}$ based on LSD test at level $5 \%$. By the treatment of $1.5 \mathrm{~kg}$ compost from household waste $+40 \mathrm{ml} / 500 \mathrm{ml}$ water of liquid organic fertilizer $\left(\mathrm{K}_{3} \mathrm{C}_{2}\right)$, weight of Pak Choi increased $12.34 \%$ in comparison with the treatment $1.5 \mathrm{~kg}$ + liquid organic fertilizer $40 \mathrm{ml} / 500 \mathrm{ml}$ water $\left(\mathrm{K}_{2} \mathrm{C}_{2}\right)$.

Lahadassy et al. (2007), in order to achieve optimal fresh weight, the crop requires great amount of energy and nutrients to increase the numbers and to achieve optimal cellular size, as well as enable it to increase water content due to most of fresh weight of the crop is affected by water content. Water plays important role in cellular turgidity, which will make the leaf cells grow bigger.

Nutrient status in plant tissues and plant growth is shown by deficiency and sufficiency zones. In deficiency zone, supplementing any nutrients may cause more weight on the crop, while in the sufficiency zone, supplementing 
the nutrients may increase the nutrient contents in the plant tissues, but it would not increase the harvest yield. (Gardner et al., 1991 in Erawan et al. 2013). Nitrogen will promote growth of the vegetative part, such as leaf (Jumin, 2002). It conformed to the suggestion by Lingga and Marsono (2007), the main role of nitrogen for the plant is to stimulate growth, particularly stems, brances, and leaves.

The application effect of compost from household waste and liquid organic fertilizer on fresh weight of pakchoy is caused by the content of such compost, which include both macro-and-micro nutrients. Macronutrients include $\mathrm{C}, \mathrm{H}, \mathrm{O}, \mathrm{N}, \mathrm{S}, \mathrm{P}, \mathrm{K}, \mathrm{Ca}$, and $\mathrm{Mg}$. In general, macronutrients function as the main composer of plant structures. The increasing structure of plant will increase its biomass, so that the crop weight will increase as well. Macronutrients play important roles, such as nitrogen, in maintaining vegetative growth that will make the crop become bigger and green. Nitrogen deficiency will be obviously seen in the retarding growth, stunted, and premature flowering (Hopkins and Norman, 2008).

Higher dose of organic fertilizer of petroganic application will provide higher $\mathrm{N}$ in crop. It is due to organic fertilizer of petroganic has experienced fermentation process and contains high $\mathrm{C} / \mathrm{N}$ ratio (10-25\%). Such condition may increase $\mathrm{N}$-total in the soil (Buckman and Brady, 1982). The increasing application of organic fertilizer will increase Nitrogen, which is absorbed by the crop. Nitrogen is an essential macro nutrient, which is required in great amount by the crop to create chlorophyll, protein, fat, and various organic fusion of chemical compounds.

Correlation between crop characteristics against fresh weight of pakchoy has positive connection and in chronological orders started from characteristics that have the highest positive correlation : crop height at week-3 $(r$ : $\left.0.927^{* *}\right)$, crop height at week-4 ( $\left.r: 0.927^{* *}\right)$, crop height at week-3 $\left(r: 0.927^{* *}\right)$, crop height at week-3 $\left(r: 0.902^{* *}\right)$, high numbers of leaf at week-4 $\left(r: 0.896^{* *}\right)$, crop height at week-2 $(r$ : $\left.0.893^{* *}\right)$, numbers of leaf at week-2 ( $r$ : $\left.0.759^{* *}\right)$, and numbers of leaf at week-1 ( $r$ : $0.634^{* *}$ ) (Haryati et al., 2014).

\section{CONCLUSION}

Results of analysis in laboratory showed that organic fertilizer made of organic waste from household waste $100 \%$ + Superdegra + goat dropping (manure) + bran + molasses produce $\mathrm{C}$-organic $=18.89$ and $\mathrm{C} / \mathrm{N}$-ratio $=17.33$. Results of the research showed that physical characteristics and $\mathrm{C} / \mathrm{N}$-ratio, composts from organic waste of household have met the requirements as organic fertilizer. Combination of treatment, which is comprised of organic waste of household $100 \%+$ Superdegra decomposer + goat dropping (manure) + bran + molasses $1.5 \mathrm{~kg} /$ polybag + liquid organic fertilizer $40 \mathrm{ml} / 500 \mathrm{ml}$ water $\left(\mathrm{K}_{3} \mathrm{C}_{2}\right)$ will be able to produce fresh weight of pakchoy 126.38 gram/polybag.

\section{REFERENCES}

Annisava, A. R. 2013. Optimizing the growth and content of your vitamin C (Brassica alboglabra L.) using bokshi and fermented plant extracts. Journal of Agrotechnology. Vol 3 (2):1-10.

Araujo, W.L., R.F. Alisdair, R.F., dan N. Adriano. 2011. Control of stomatal aperture: $A$ renaissance of the old guard. Plant Signalling and Behavior. Vol 6 (9): 1305-1311.

Buckman, H. O., and N. C. Brady. 1983. Soil Science (Translation). : Bharata Karya Aksara. Jakarta.

Boonsiri K., S. Dawrung, P Siri, S. Angcharee, T Wirung, K. Jeerasak K. dan W. Apiwat. 2009. Effect of granular organic fertilizers on the growth and yield of Pak Choi and rice cv. Phitsanulok 60-2. Asian Journal of Food and AgroIndustry, p.160-163. 
Cahyono, B. 2005. Spring onion : Cultivation techniques and farm analysis. Publisher Kanisius. Yogyakarta.

Cruz, P.C., Nino P.M., Severino R.M., Mylalulex A.M., Danilo J.L., \& Jose E.H. 2012. Bioinoculant and foliar fertilizer in combination with soil-apllied fertilizer on the yield of lowland rice. Philippine Journal of Crop Science. 37 (3) : 85-94.

Department of Agriculture. 2015. Food consumption statistics 2015 : Average per capita consumption of mustard greens in Indonesia. http://epublikasi.setjen.pertanian.go.id. Retrieved January 12, 2019.

Dewanto, F. G., Londok, J. J. M. R., dan R.A.V. Tuturoong. Effect of Inorganic and Inorganic Fertilization on Corn Production as a Feed Source. Zootek Journal. Vol 32 (5) : $1-8$.

Djoehana. S. E. 1986. Fertilizer and Fertilization. CV Simplek. 35p.

Edwards S., and Hailu A. 2010. How to make and use compost. Institute for Sustainable Development Press.

Erawan, D., Wa Ode, Y., and Bahrun. 2013. Growth and Yield of Mustard (Brassica juncea L.) at Various Doses of Urea. Agroteknos Journal. Vol. 3 (1) : 19 - 25.

Ganesan S., Kurucheve V., \& Jayaraj J. 2015. Sustainable crop disease management using natural products. CAB International. Massachusetts.

Gasperz, V. 1995. Analytical Techniques in Experimental Research. Volume I. Tarsito. Bandung.

Gomez, A. K and A. Gomez. 1993. Statistical Procedures for Agricultural Research. 2nd Edition. Los Banos.

Haryati, Y., Sukmaya, dan S. Mindarti. 2014. Study of Planting Media on the Growth and Yield of Mustard in Bogor City. Journal of the Assessment and Development of Agricultural Technology. Vol. 17 (3) : 223 - 230.

Kant S., David B., Pieter B., Rajasekaran P., John M., \& German S. 2014. Regulated expression of a cytokinin biosynthesis gene IPT delays leaf senescence and improves yield under rainfed and irrigated conditions in canola (Brassica napus L.). Journal PLOS ONE, 1-18. DOI: 10.1371/journal.pone.0116349.

Kuruseng, M. A. 2012. The effect of bokashi residue on the growth and production of mustard greens. Journal of Agrisistem. Vol 8 (1): $27-35$.

Kusuma. 2012. Effect of quail manure dosage on growth and yield of chicory (Brassica juncea L.). Tropical Animal Science Journal. Vol 1 (1):1- 5 .

Lahadassy, J., A. M. Mulyati, dan A. H. Sanaba. 2007. Effect of Concentration of Gamal Leaf Solid Organic Fertilizer on Mustard Plants. Journal of Agrisistem. Vol 3 (6) : 51-55.

Lingga, $\mathrm{P}$ dan Marsono. 2007. Instructions for Use of Fertilizers. Revised Edition. Penebar Swadaya. Jakarta.

Nathania, B., Sukewijaya, I. M., dan N. W. S. Sutari. 2012. Effect of elephant biourine application on growth and yield of mustard green mustard (Brassica juncea L.). E-Journal of Tropical Agrotechnology. Vol. 1 (1) : $72-85$.

Novizan, N. 2005. Instructions for effective fertilization. PT. Agromedia Pustaka. Jakarta.

Price, J. 2010. The simple art of eating well: Cook book. Eating Well, Inc. Charlotte.

Sarpian, T. 2003. Pepper gardening guidelines and farm analysis. Penerbit Kanisius. Yogyakarta

Sastrosupadi, A. 2005. Practical Experiment Design in Agriculture. Publisher PT Kanisius. Yogyakarta. 243p.

Silvia, M., Sugian Noor, G. M., dan M. E. Erhaka. 2012. Growth response and yield of cayenne pepper (Capsicum frutescent L.) to the application of goat manure on ultisol soil. Agroscientie Journal. Vol 19 (3) : 148 - 154.

Wahyono, S., Firman I.S., and Feddy S. 2011. Making granular organic fertilizer from various wastes. PT. Agromedia Pustaka. Jakarta. 
White, C.A., Roques, S.E., and P.M. Berry. 2015. Effect of foliar applied nitrogen fertilizer on oilseed rape (Brassica napus). Journal of Agricultural Science, 153: 42-55.

Xu, J., Zha M., Li , Y., Ding Y., Chen L., Ding C., and S. Wang. 2015. The interaction between nitrogen availability and auxin, cytokinin, and strigolactone in the control of shoot branching in rice (Oryza sativa. L). Plant Cell Reproduction, 34(9): 1647-1662. 